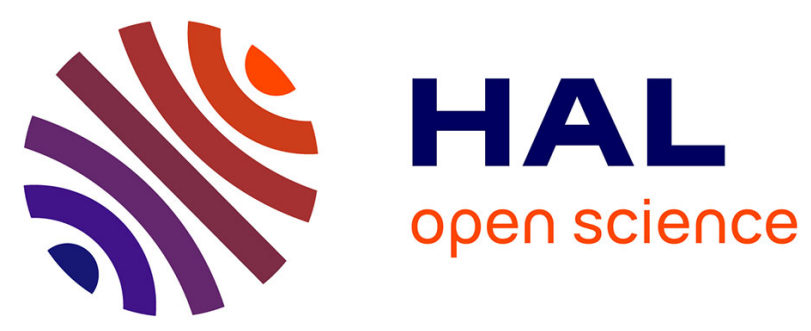

\title{
Does moder development along a pure beech (Fagus sylvatica L.) chronosequence result from changes in litter production or in decomposition rates?
}

Jean Trap, Fabrice Bureau, Alain Brêthes, Bernard Jabiol, Jean-François Ponge, Matthieu Chauvat, Thibaud Decaëns, Michaël Aubert

\section{To cite this version:}

Jean Trap, Fabrice Bureau, Alain Brêthes, Bernard Jabiol, Jean-François Ponge, et al.. Does moder development along a pure beech (Fagus sylvatica L.) chronosequence result from changes in litter production or in decomposition rates?. Soil Biology and Biochemistry, 2011, 43 (7), pp.1490-1497. 10.1016/j.soilbio.2011.03.025 . hal-00593548

\section{HAL Id: hal-00593548 \\ https://hal.science/hal-00593548}

Submitted on 16 May 2011

HAL is a multi-disciplinary open access archive for the deposit and dissemination of scientific research documents, whether they are published or not. The documents may come from teaching and research institutions in France or abroad, or from public or private research centers.
L'archive ouverte pluridisciplinaire HAL, est destinée au dépôt et à la diffusion de documents scientifiques de niveau recherche, publiés ou non, émanant des établissements d'enseignement et de recherche français ou étrangers, des laboratoires publics ou privés. 
1 Type of contribution: regular paper

2 Date of preparation: August, 2010

3 Number of text pages: 26

4 Number of figures: 4

5 Number of tables: 4

6 Number of appendixes: 1

7

8 Title

9

10 Does moder development along a pure beech (Fagus sylvatica L.) chronosequence result from

11 changes in litter production or in decomposition rates?

12

13 Jean TRAP ${ }^{\mathrm{a}}$, Fabrice BUREAU ${ }^{\mathrm{a}}$, Alain BRETHES ${ }^{\mathrm{b}}$, Bernard JABIOL $^{\mathrm{c}}$, Jean-François PONGE ${ }^{\mathrm{d}}$,

14 Matthieu CHAUVAT ${ }^{\mathrm{a}}$, Thibaud DECAËNS ${ }^{\mathrm{a}}$, Michaël AUBERT ${ }^{\mathrm{a}}$

15

16 a'Laboratoire d'Ecologie, EA 1293 ECODIV, Fédération de Recherche SCALE, Bâtiment IRESE

17 A, UFR Sciences et Techniques, Université de Rouen, F-76821 Mont Saint Aignan, France

$18{ }^{\mathrm{b}} \mathrm{ONF}$, département des recherches techniques, cité administrative Coligny, 131 rue du Faubourg-

19 Bannier, 45042 Orléans, France.

$20{ }^{\mathrm{c}}$ ENGREF, 14, rue Girardet, 54042 Nancy, France. 
21 d Muséum National d'Histoire Naturelle, CNRS UMR 7179, 4 avenue du Petit-Château, 91800

22 Brunoy, France.

23

24

25 Corresponding author. Jean Trap

26 Full telephone: $+33(0) 2235146655$

27 Fax No.: +33 (0)2 35146655

28 E-mail address: trapjean@yahoo.fr

29

30 


\section{Abstract}

33 The development of temperate deciduous and conifers forests stands usually results in

34 accumulation of forest floor organic matter and a shift from mull to moder humus forms. It has

35 been suggested that an increase in nutrient uptake by trees during their rapid growth phase leads

36 to topsoil acidification, decrease in earthworm density and thereby a decrease in litter turnover.

37 The focus question of the paper is whether the mull-moder shift occurring along forest ageing is

38 due to higher leaf litter production and/or to lower decay rates of litter. The objectives of this

39 research were to determine (1) changes in macro-morphological properties of humus forms, leaf

40 litter production, litter decay rates, soil nutrients content and $\mathrm{pH}$ along a 130-year pure beech

41 (Fagus sylvatica L.) chronosequence in Normandy (Northwest France), (2) if humus form varied

42 from mull to moder with increasing stand age, and (3) if a shift from mull to moder resulted from

43 increased litter production, decreased litter decay rates, or both. Annual litter production did not

44 change significantly along the chronosequence (mean 2.41 t.ha ${ }^{-1}$ ). In contrast, litter decay rates

45 decreased significantly during the rapid growth phase of trees. In consequence, the litter turnover

46 time (1/k) was lower in the youngest stands (20 months) compared to the oldest ones (31

47 months). Even in the absence of a significant pattern of variation, litter production was positively

48 correlated with the thickness of the OF (Oi) horizon. In contrast, litter decay was strongly

49 negatively correlated with maximum thickness of the $\mathrm{OH}(\mathrm{Oa})$ horizon, suggesting that the

50 appearance of the humification layer was mainly due to a decrease in litter decay rate. We did not

51 find significant changes in the main properties of the organo-mineral horizon, suggesting that soil

52 nutrient availability may not directly affect litter dynamics. We concluded that moder

53 development along the chronosequence resulted in decreasing litter decay rates during the 
54 aggradation phase while litter production was stable. Further studies are required to identify the 55 ecological factors responsible for moder development along forest ageing.

56

\section{$57 \quad$ Keywords}

58

59 Litter production, litter decomposition rate, humus form, nutrient availability, 130-yr

60 chronosequence, Fagus sylvatica, loamy acidic soil, forest management.

61

62 


\section{Introduction}

Successional patterns of humus forms have often been described along both temperate

deciduous and conifers managed (Aubert et al., 2004; Chauvat et al., 2007) and native forest

67 maturation (Bernier and Ponge, 1994; Ponge and Delhaye, 1995). Early successional stages have

been associated with fast organic matter turnover (translated into mull humus form) while lower

organic matter $(\mathrm{OM})$ recycling (expressed as moder occurrence) has been frequently observed

under older forest on acidic soils (soil pH < 5.0) (Ponge, 2003; Salmon et al., 2006). More

precisely, the appearance of moder with stands ageing consists in development of both

72 fragmentation and humification litter layers, including high proportions of fine organic matter

73 from fauna faeces.

Accumulation of organic materials on the forest floor results from unbalanced rates of two

\section{5}

76

77

78

79

80

81

82

83

84

85 ecological processes: litter production and litter decomposition. For instance, the gradually higher amount of organic matter falling each year along stands ageing may not be fully incorporated within mineral horizons by soil organisms. Only soluble and non-lignified cell carbohydrates are totally utilized during the early phases of leaf litter decomposition (Lavelle and Spain, 2001; Berg and McClaugherty, 2003). Each year, more and more recalcitrant compounds (lignified carbohydrates) may accumulate within the forest floor and promote the formation of fragmented and humified horizons (Lebret et al., 2001).

Besides litter production, changes in litter decay rates may also lead to the appearance of a humification horizon. Ponge (2003) and Ponge et al. (1998) assumed that higher uptake of nutrients by trees during their phase of intense growth, for wood production, may lead to lower nutrient availability in the soil thereby affecting soil biological activity, especially earthworms 
activity. Indeed, there is also a global trend of decreasing abundance of earthworms during the

87 phase of intense growth of temperate trees (Bernier and Ponge, 1994; Arpin et al., 1998). This may lead to a decrease in litter decay rates promoting the accumulation of fragmentation and

89 humification litter layers. Nevertheless, Hedde et al. (2007) did not find any significant changes

90 in macrofaunal species turnover along a 200 years old pure beech chronosequence in France

91 despite clear changes in humus forms suggesting that others factors than earthworm occurrence

92 may be implicated.

93 The question of the paper was whether the shift mull-moder occurring along beech forest 94 ageing is due to changes in leaf litter production and/or decay rates. More exactly, the objectives 95 of this research were to determine (1) changes in macro-morphological properties of humus 96 forms, leaf litter production, litter decay rates, soil nutrients content and $\mathrm{pH}$ along a 130-year

97 pure beech (Fagus sylvatica L.) chronosequence Normandy (Northwest France), (2) if humus

98 form changed from mull to moder with increasing stand age, (3) if a shift from mull moder

99 resulted from increased litter production, decreased litter decay rates, or both. We also aimed at 100 validating in a managed context the hypothesis developed by Ponge (2003) about soil properties

101 (nutrients content and $\mathrm{pH}$ ) impact on moder appearance. We tested the hypothesis that 102 fragmented and humified organic materials would accumulate within the forest floor due to 103 decreasing litter decay rates and increasing litter production (Lebret et al., 2001). We also 104 expected the decrease in nutrients availability and $\mathrm{pH}$ within the organo-mineral horizon with 105 moder appearance (Ponge, 2003; Aubert et al., 2004).

\section{Materials and methods}

108 2.1. Study site 
110 The study site was located in the Eawy state forest (France, Upper Normandy, $01^{\circ} 18^{\prime} \mathrm{E}$;

$\left.11149^{\circ} 44^{\prime} \mathrm{N} ; 7200 \mathrm{ha}\right)$. The climate is temperate oceanic with a mean annual temperature of $+10^{\circ} \mathrm{C}$

112 and a mean annual precipitation of $800 \mathrm{~mm}$. A space-for-time substitution procedure (Pickett,

113 1989) was used to empirically reconstitute an even-aged forest chronosequence: sixteen pure

114 beech stands were selected to represent four silvicultural phases (SP) (Aubert et al., 2003) of

115 different ages: 13-18 years (SP15), 65-66 years (SP65), 91-103 years (SP95) and 121-135 years

116 (SP130) (Table 1). Each phase was comprised of four replicated stands. All stands were managed

117 as even-aged full-grown forest by the French Forestry Service (Office National des Forêts -

$118 \mathrm{ONF}$ ) and were located on a flat (plateau) topography at $205 \mathrm{~m}$ (a.s.1). The soil was an endogleyic

119 dystric Luvisol (FAO, 2006) developed on more than $80 \mathrm{~cm}$ of loess (lamellated silt of aeolian

120 origin) lying on clay with flints (Laignel et al., 1998). Understory vegetation was defined as a

121 characteristic Endymio-Fagetum according to phytosociological classification (Durin et al.,

122 1967). At the centre of each stand, a $16 \mathrm{~m}^{2}$ square plot was delimited away from vehicle tracks

123 and base of trees to avoid any local acidification due to the influence of tree stems (Beniamino et

124 al., 1991).

125

126

2.2. Morphology of organic and organo-mineral horizons

127

Macro-morphological descriptions of organic and organo-mineral horizons were

129 previously conducted within frames $(25 \mathrm{~cm} \mathrm{x} 25 \mathrm{~cm})$ at three corners of the central plot according

130 to the French nomenclature of soil horizons (Jabiol et al., 2007) in May 2007 (Table 2). We

131 distinguished mull (mainly dysmull) and moder (hemimoder + eumoder + dysmoder) humus 
132 forms on the basis of morphological characters (Table 2). A total of 36 macro-morphological 133 variables were described in the field on the basis of variation visible to the naked eye (Appendix

134 1) and 48 humus profiles were described ( 3 profiles per stand $\times 16$ stands). We differentiated (1)

135 the OL horizon consisting of almost unmodified leaf and woody fragments; (2) the OF horizon

136 consisting of a mixture of coarse plant debris and fine organic matter (humus); (3) the $\mathrm{OH}$

137 horizon, which is an organic horizon characterized by an accumulation of decomposed plant litter

138 and (4) the organo-mineral (A) horizon which vary in depth and structure among humus forms.

140 2.3. Chemical properties of the organo-mineral horizon

Four subsamples of the organo-mineral horizon were collected in May 2007 within 143 frames $(25 \times 25 \mathrm{~cm})$ located at each corner of the central square plot. In the laboratory, samples 144 were sieved to $2 \mathrm{~mm}$ and air-dried until stable weight. Subsamples were dried at $105^{\circ} \mathrm{C}$ during $14524 \mathrm{~h}$ to determine water content. In air-dried samples of the organo-mineral horizon, 146 concentrations of total $\mathrm{C}$ and $\mathrm{N}$ were measured by gas chromatography with a CHN pyrolysis 147 micro-analyser (Flash 2000 Series, CHNS/O Analysers Thermo Scientific, IRCOF, France). C148 to- $\mathrm{N}$ ratio, $\mathrm{pH}_{\text {water }}$ and $\mathrm{pH}_{\mathrm{KCl}}$ (soil-to-solvent ratio $=1 / 2.5$, WTW $\mathrm{pH}$ Meter 340, Weilheim, 149 Germany) (Baize, 2000), available P (Duchaufour and Bonneau, 1959), and Cation Exchange 150 Capacity (CEC) were also determined in the samples as well as total elements (Ca, $\mathrm{Mg}, \mathrm{K}, \mathrm{Mn}$, $151 \mathrm{Na}, \mathrm{Al}, \mathrm{Fe}$ ) by the cobalt hexamine exchange method (Ciesielski and Sterckeman, 1997). 
156 order to characterize the annual litter production. Three collectors were placed in each stand near

157 to the $16 \mathrm{~m}^{2}$ plot (less than $20 \mathrm{~m}$ ) along a $40 \mathrm{~m}$ transect at 0,20 and $40 \mathrm{~m}$. Litter was sampled every

158 month from October 2007 to October 2008. A total of 48 collectors were installed (3 collectors

159 per stand x 16 stands). Litterfall samples were oven-dried at $65^{\circ} \mathrm{C}$ for $48 \mathrm{~h}$ (Gardner, 2006). Dry

160 samples were sorted and litter components were classified into categories then weighed. Litter

161 categories were leaves, wood fragments and reproductive organs. The wood category included

162 dead wood and bark. Reproductive organs included beech mast and male flowers. Litter was

163 stored at room temperature for litterbag experiment described below.

\subsection{Litter decay}

We sampled leaf litter in one stand of each silvicultural phase in November 2007 using a

net $\left(24 \mathrm{~m}^{2}\right.$ surface $)$ tight one meter above the forest floor in order to avoid any colonization by room temperature before the experiment. Litter decay was assessed in each silvicultural phase 171 using the litterbag method (Bocock and Gilbert, 1957; Verhoef, 1995). Litterbags (15 x 20cm)

172 were made from nylon net with $0.175 \mathrm{~mm}$ mesh size to only exclude macrofaunal activity 173 (Gartner and Cardon, 2004; Aubert et al., 2010). They were filled with 10g of dried leaves. This 174 amount of litter corresponds to the mean annual leaf litter production in French beech forests 175 according to Lebret et al. (2001). Four different litterbag types were prepared, consisting of litter 176 from four tree age-classes $(15,65,95$ and 130 years). In each stand, litterbags filled with the 177 respective litter were inserted in the forest floor between OL and OF horizons. Litterbags were 
178 placed in the field in December 2007. For each silvicultural stage, 4 replicate bags (one per stand)

179 were removed 12 months after the start of the experiment. When removed, litterbags were packed

180 in plastic bags and transported to the laboratory for analyses. The content was then oven dried at $18165^{\circ} \mathrm{C}$ for $48 \mathrm{~h}$ to determine litter dry mass (Gardner, 2006).

\subsection{Data treatment and statistical analyses}

The decay rate coefficient $(k)$ estimates the disappearance of litter on an annual basis,

186 using the following negative exponential decay function:

$187 \quad \mathrm{X}_{\mathrm{t}} / \mathrm{X}_{0}=\mathrm{e}^{-k \mathrm{t}}$

188 where $X_{0}$ is the original mass of litter and $X_{t}$ is the mass remaining at time $t$ (Olson 1963). The $k$

189 value $\left(\right.$ month $\left.^{-1}\right)$ was used to assess the turnover time of litter (1/k) (Olson, 1963).

All tests were computed with the $\mathrm{R}$ freeware (R Development Core Team, 2008) and

191 statistical significance was set at $P<0.05$. Means and standard deviations were calculated for 192 each silvicultural phases ( $\mathrm{n}=4$ replicates). Comparisons of means were done among silvicultural 193 phases using one-way ANOVA and Tukey HSD post-hoc tests. The normality of data and the 194 homogeneity of variances were previously checked using Wilk-Shapiro (Royston, 1982) and

195 Bartlett tests (Bartlett, 1937), respectively. A Principal Component Analysis (PCA) was 196 performed on organo-mineral horizon properties in order to present a clearer representation of 197 topsoil parameters variations along the beech chronosequence (variables are listed in table 3). We 198 also performed backward-stepwise multiple regressions to discern soil morphological variables 199 that were significantly related to both litter production and litter decay along the chronosequence, 200 after screening potential independent variables for significant co-variation $\left(\mathrm{R}^{2}>0.90\right)$. 


\section{Results}

3.1. Litter production along the chronosequence

Due to high inherent variability, leaf production did not vary among silvicultural phases

(Figure 1). It exhibited the lowest average value in SP15 (2.08 t.ha $\left.{ }^{-1}\right)$ and the maximal one in

SP65 (2.58 t.ha $\left.{ }^{-1}\right)$. Similarly to leaf litter, wood production did not change between silvicultural

phases. In contrast, the production of reproductive organs show significant variations with higher

values in SP130 and lower ones in SP65. Leaf was the most abundant component of litterfall in all silvicultural phases. Wood was the second one except for SP130 where reproductive organs were most abundant (Figure 1). Total litter production (leaves + reproductive organs + wood) did not vary significantly among silvicultural phases (Figure 2) but exhibited its highest values in

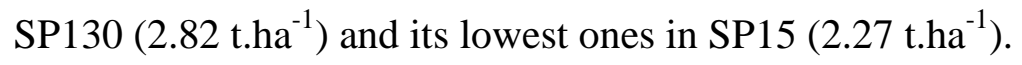

\subsection{Litter decomposition along the chronosequence}

After 12 months of litterbag experiment, SP95 and SP130 exhibited a significantly higher 218 remaining mass percentage (68 and 65\%, respectively) compared to SP15 (53\%) (Figure 2). The 219 decay rate coefficient $(k)$ was significantly higher in SP15 (0.050 month $\left.^{-1}\right)$ compared to SP95

$220\left(0.032\right.$ month $\left.^{-1}\right)$ while the turnover time (1/k) was significantly lower in SP15 (20 months) 221 compared to older stands (31 and 28 months in SP95 and SP130, respectively) (Figure 3). 
225 We did not observe any significant change in chemical properties in the organo-mineral 226 horizon, except for the Mg pool (Table 3). Soil Mg content was higher in SP15 compared to SP65 227 and SP130. Even insignificant, $\mathrm{CEC}, \mathrm{Ca}$ and $\mathrm{Na}$ contents as well as $\mathrm{pH}_{\mathrm{water}}$ and $\mathrm{pH}_{\mathrm{KCl}}$ decreased 228 slightly along the chronosequence, while $\mathrm{P}, \mathrm{H}$ and $\mathrm{Al}$ contents and $\Delta \mathrm{pH}$ tended to increase. The first two axes of the PCA performed on organo-mineral horizon data explained

$23061.1 \%$ of the total variation (Fig. 4.A). The first axis (relative inertia $=39.1 \%$ ) was highly correlated with organic matter content, total $\mathrm{C}$, total $\mathrm{N}, \mathrm{CEC}$ and $\mathrm{C} / \mathrm{N}$ ratio (positives scores). The 232 second one (relative inertia $=21.9 \%$ ) was highly correlated with $\mathrm{pH}, \mathrm{pH}_{\mathrm{water}}, \mathrm{Al}$ (negative scores) and $\mathrm{Ca}, \mathrm{Mg}$ and $\mathrm{Na}$ (positive scores) (Fig. 4.A.). The individual factor maps (Figure 4.B) did not

234 discriminate the silvicultural phases and humus forms.

\subsection{Humus forms and litter dynamics co-variation patterns}

242 skeletonized and brown leaves in OLv $\left(P<0.05, \mathrm{R}^{2}=0.62\right)($ Table 4$)$.

\section{Discussion}


Our results showed that litterfall production did not change significantly along the pure

248 beech chronosequence. The absence of significant differences agrees with Starr et al. (2005) who

249 did not find any correlation between stand age and litterfall production in Scots pine forest in

250 Finland. Nevertheless, even insignificant, litterfall production tended to increase during the rapid

251 growth phase of trees. This trend was also observed by Lebret et al. (2001). In their study, beech

252 litter production varied from $1.15 \mathrm{t} \mathrm{ha}^{-1} \mathrm{yr}^{-1}$ in a thicket stand (10-yr-old) to $3.13 \mathrm{t} \mathrm{ha}^{-1} \mathrm{yr}^{-1} \mathrm{in} \mathrm{a}$

253 mature stand (147-yr-old) from the Fougères forest in western France.

254 Besides climate and soil conditions, changes in litter production were often related to

255 stand structure such as relative basal area, breast height diameter of trees or mean height and

256 thinning intensity (Ranger et al., 1995; Lebret et al., 2001; Saarsalmi et al., 2007). In the present

257 study, we did not find any significant relationship between stand structure variables and litter

258 production. Higher foliar biomass per tree in mature stands may compensate for decrease in tree

259 density along the chronosequence, leading to constant litter production. However, we showed that

260 the litter decomposition rate varied to a great extent along the chronosequence, the mean

261 residence time of beech leaves passing from 20 months at 15 years to more than 30 months at 95

262 years, i.e. during the phase of rapid growth of beech trees. These changes in litter decay may be

263 related to changes in the activity of soil organisms (Berg and Laskowski, 2006). For instance,

264 Ponge (2003) explained that anecic earthworms populations are particularly sensitive to tree

265 development due to soil acidification in the vicinity of tree trunks (Ponge and Delhaye, 1995;

266 Salmon et al., 2006). The abundance of anecic earthworms tends to decrease during the phase of

267 intense growth of trees followed by progressive recovery as trees reach maturity then senesce

268 (Bernier and Ponge, 1994). However, Hedde et al. (2007) did not find any significant

269 macrofaunal species turnover along 200 years of pure beech chronosequence, using the same site 
270 as in the present study. The authors assessed that the lack of change in species composition along

271 the chronosequence might reflect the confounding effect of silvicultural practices, i.e.

272 monoculture of a soil-acidifying tree species on acidic soils and the use of tillage to assist natural

273 regeneration. Those practices may have dramatic impacts on burrowing earthworms. The soil $\mathrm{pH}$

274 might be too much acid even in youngest stands $\left(\mathrm{pH}_{\text {water }} 3.97\right)$ to permit high anecic earthworm

275 abundance. Finally, according to Hedde et al. (2007) results, the observed changes in litter decay

276 rates may not be related to earthworm community structure and activity.

277 Other explanation lies on the high lignin content of beech litter (Karroum et al., 2005;

278 Sariyildiz and Anderson, 2005; Hobbie et al., 2006). Fagus sylvatica is a woody species which

279 produces low quality leaf litter with a high content of lignin and a low content of nitrogen

280 (Sariyildiz and Anderson, 2003b; Hobbie et al., 2006) compared to early successional species

281 such as birch (Betula pendula) or hornbeam (Carpinus betulus). Karroum et al. (2004; 2005)

282 showed that lignin degradation occurring in organic layers of beech forests consists in an increase

283 in the vanillic acid/aldhehyde ratio. The production of phenolic monomers during lignin

284 degradation probably leads to strong acidification in both organic and organo mineral horizons

285 during forest development. Consequently, microbial activity may vary and thus may affect litter

286 decay rates. An investigation of litter quality along the chronosequence may provide insights in

287 our understanding in moder development with forest ageing. It would be also interesting to

288 investigate the structure and function of soil microbial communities in both the organic and

289 organo mineral layers to validate this hypothesis (Idol et al., 2002).

290

291

4.2. Humus forms and litter dynamics co-variation patterns

292 
294 were positively correlated with the maximum thickness of the OF layer, suggesting a possible 295 effect of litterfall increase on moder development. They were also highly correlated with the 296 percentage of bleached leaves (discolored leaves due to fungal activity) in the OLv horizon and 297 were negatively correlated with the number of earthworm casts in the OLn horizon. It is probable 298 that a higher beech leaf litter production favored the fungal community, in particular white-rot 299 fungi (Karroum et al., 2005) due to a higher amount of phenolic recalcitrant compounds (lignified 300 carbohydrates and polyphenol-protein complexes) in litter, which may accumulate within the 301 forest floor along the chronosequence. This hypothesis is supported by Karroum et al. (2005) 302 who investigated the morphological evolution of beech litter and biopolymer transformation in 303 humus forms from the Fougères forest (northwestern France). They showed that fungal attacks 304 occurred mainly within the OL and OF horizons while bacterial activity was high within the OF 305 and especially the $\mathrm{OH}$ horizons where they were responsible for the structural degradation of 306 polysaccharides. The gradually higher amount with stands ageing of lignin-rich leaf litter falling 307 each year may promote the fungal community within the OL layer, a spatial segregation of soil 308 decomposers and consequently the thickening of the fragmentation layer in the absence of anecic 309 earthworm activity (Lebret et al., 2001; Salmon et al., 2006). Our results also showed that litter 310 production was significantly correlated with the abundance of live roots in the OLv horizon. We 311 indeed observed a higher root colonization in $\mathrm{OF}$ and $\mathrm{OH}$ horizons along the studied 312 chronosequence. This statement corroborated results by Ehrenfled et al. (1992) who found that as 313 forest floor material accumulates along coniferous forest development, the percentage of fine 314 roots increases within organic horizons. Since beech is a strongly ectomycorrhizal species 315 (Taylor et al., 2000), the presence of roots in $\mathrm{OF}$ and $\mathrm{OH}$ horizons may promote the 
316 ectomycorhizal fungal community in organic litter layers and in turn limits decomposer activity 317 (Ehrenfeld et al., 1997).

318 We showed that litter decay rates were highly correlated with the maximum thickness of 319 OH horizons, suggesting that the development of moder may result from the decrease in litter 320 decay rates observed in SP95. The litter decay rate was also negatively correlated with the 321 maximum thickness of the OF horizon and the percentage of skeletonized and brown leaves in 322 the OLv horizon, suggesting that changes in mesofaunal and enchytraeid communities may take 323 place along the chronosequence and greatly affect litter decay rates (Chauvat et al., 2007).

4.3. Soil nutrient availability as a controlling factor of humus form development?

We did not observe significant changes in nutrient availability within the organo-mineral

328 horizon along the chronosequence. Furthermore, the PCA did not discriminate the four

329 silvicultural phases and the humus forms. The first principal component described changes in 330 organic matter content and CEC while the second one reflected changes in soil acidity. These 331 results suggest that the variability in organo - mineral horizon properties among stands was not 332 related to forest ageing.

However, even insignificant, we observed a trend of decreasing soil quality ( $\mathrm{pH}$ and 334 nutrient availability) along the chronosequence, i.e. $\mathrm{pH}_{\mathrm{water}}$ was maximum in $\mathrm{SP} 15$ and minimum 335 in $\mathrm{SP} 95, \mathrm{pH}_{\mathrm{KCl}}$ showed the same pattern, with 3.33 in SP15 and 3.09 in SP95, the Ca content in 336 the organo mineral horizon was maximum in SP15 $\left(1.43 \mathrm{cmol}+\mathrm{kg}^{-1}\right)$ and minimum in SP95 $337\left(0.71 \mathrm{cmol}+\mathrm{kg}^{-1}\right)$ while the $\mathrm{Al}$ content showed an inverse pattern. This trend agrees with results 338 by Aubert et al. (2004) and Chauvat et al. (2009). They both observed an acidification of the 
339 organo mineral horizon along chronosequences of pure beech stands. The decrease in soil

340 nutrient availability along forest maturation was often related to higher nutrient uptake by trees

341 during the phase of intense growth of trees in response to nutrient requirements for wood building

342 (Brais et al. 1995, Ponge 2003). Since mineral weathering (a stable process in mineral element

343 production along forest maturation) may not supply enough nutrients (base cations) for beech tree

344 requirements, soil quality might decrease along a pure beech chronosequence (Brais et al., 1995;

345 Trap et al., 2009), affecting in turn litter decay. This hypothesis is supported by Sariyildiz and

346 Anderson (2003a) who showed that after 12 months of laboratory incubation, both oak (Quercus

347 robur L.) and beech litter decomposition rates varied greatly according to soil quality. It can be

348 wondered whether these changes in soil nutrient availability were significant enough to be

349 responsible for the accumulation of organic material along the pure beech chronosequence.

\section{Conclusions}

Our results showed that the appearance of moder under the oldest stands was likely to be 354 due to decreasing litter decay rates during the rapid growth phase of trees while litter production 355 was constant. The first hypothesis formulated in the introduction is thus partially validated. 356 However, we cannot validate the second hypothesis concerning topsoil nutrients concentration 357 and $\mathrm{pH}$ which should decrease along the pure beech chronosequence and limits soil biological 358 activity (direct effect) and consequently litter decomposition rates. Indeed, we did not find any 359 significant linear correlations between litter dynamics and organo-mineral horizon properties, and 360 the PCA performed on those latter did not discriminate the silvicultural phases and humus forms. 361 Finally, we can conclude that soil nutrient availability effects on litter decay rates were either 
362 limited or not linear. These findings raise questions about the ecological factors responsible for 363 the decrease of litter decay rates and thereby moder development with stand ageing which remain 364 unknown. In the challenge to improve forest soil health and quality, further investigations are 365 thus required, maybe by manipulating potential causative factors in long-term experiments.

367 Acknowledgements

370 to J. Trap through the SCALE network of the GRR SER. This research was funded by both the 371 SCALE network and the GIP ECOFOR (Viflorhum program). We want to thank P. Delporte, T.

372 Tallec, B. Richard, G. Perez and P. Margerie (University of Rouen) for their assistance during 373 litter collection and J.-F. Cheny (ONF) for his help in stand choice. 


\section{References}

Arpin, P., Ponge, J.F., Faille, A., Blandin, P., 1998. Diversity and dynamics of eco-units in the biological reserves of the Fontainebleau forest (France): Contribution of soil biology to a functional approach. European Journal of Soil Biology 34, 167-177.

Aubert, M., Alard, D., Bureau, F., 2003. Diversity of plant assemblages in managed temperate forests: a case study in Normandy (France). Forest Ecology and Management 5975, 1-17.

Aubert, M., Bureau, F., Alard, D., Bardat, J., 2004. Effect of tree mixture on the humic epipedon and vegetation diversity in managed beech forests (Normandy, France). Canadian Journal of Forest Research 34, 233-248.

Aubert, M., Margerie, P., Trap, J., Bureau, F., 2010. Aboveground-belowground relationships in temperate forests: plant litter composes and microbiota orchestrates. Forest Ecology and Management 259, 563-572.

Baize, B., 2000. Guide des analyses en pédologie. INRA Editions, Paris, 257 pp.

Bartlett, M.S., 1937. Bartlett, M. S. (1937). Properties of sufficiency and statistical tests. Proceedings of the Royal Society of London Series A 160, 268-282. Proceedings of the Royal Society of London Series A 160.

Beniamino, F., Ponge, J.F., Arpin, P., 1991. Soil acidification under the crown of oak trees .I. Spatial-distribution. Forest Ecology and Management 40, 221-232.

Berg, B., McClaugherty, 2003. Plant litter. Decomposition, humus formation, carbon sequestration. Springer, Berlin, 286 pp.

Berg, B., Laskowski, R., 2006. Decomposers: Soil Microorganisms and Animals. Advances in ecological research 38, 73-100. 
399

400

401

402

403

404

405

406

407

408

409

410

411

412

413
Bernier, N., Ponge, J.-F., 1994. Humus form dynamics during the silvigenetic cycle in a mountain spruce forest. Soil Biology and Biochemistry 26, 183-220.

Bocock, K.L., Gilbert, O.J.W., 1957. The disappearance of leaf litter under different woodland conditions. Plant and Soil, 179-185.

Brais, S., Camiré, C., Bergeron, Y.P., D., 1995. Changes in nutrient availability and forest floor characteristics in relation to stand age and forest composition in the southern part of the boreal forest of northwestern Quebec. Forest Ecology and Management 76, 181-189.

Brêthes, A., Brun, J.J., Jabiol, B., Ponge, J.-F., Toutain, F., 1995. Classification of forest humus forms: a french proposal. Annales des Sciences Forestières 52, 535-546.

Chauvat, M., Ponge, J.F., Wolters, V., 2007. Humus structure during a spruce forest rotation: quantitative changes and relationship to soil biota. European Journal of Soil Science 58, 625-631.

Chauvat, M., Zaitsev, A.S., Gabriel, E., Wolters, V., 2009. How do soil fauna and soil microbiota respond to beech forest growth? Current Zoology 55, 272-278.

Ciesielski, H., Sterckeman, T., 1997. Determination of cation exchange capacity and exchangeable cations in soils by means of cobalt hexamine trichloride. Effects of experimental conditions. Agronomie 17, 1-7.

Duchaufour, P., Bonneau, M., 1959. Une méthode nouvelle de dosage du phosphore assimilable dans les sols forestiers. Bulletin de l'AFES 4, 193-198.

Durin, L., Géhu, J.-M., Noirfalise, A., Sougnez, N., 1967. Les hêtraies atlantiques et leur essaim climatique dans le nord-ouest et l'ouest de la France. Bulletin de la Société Botanique du Nord de la France 20, 66-89. 
421 Ehrenfeld, J.G., Kaldor, E., Parmelee, R.W., 1992. Vertical-distribution of roots along a soil 422 toposequence in the New-Jersey Pinelands. Canadian Journal of Forest Research 22, 1929-1936.

424 Ehrenfeld, J.G., Parsons, W.F.J., Han, X.G., Parmelee, R.W., Zhu, W.X., 1997. Live and dead roots in forest soil horizons: contrasting effects on nitrogen dynamics. Ecology 78, 348362. correlation and communication. Food and Agriculture Organization of the United Nations, Roma, 145 pp. M.M., D.R., N. (Eds.), Methods of soil analysis part I: Physical and Mineralogical Methods Soil Science Society of America, Inc., pp. 493-544.

Gartner, T.B., Cardon, Z.G., 2004. Decomposition dynamics in mixed-species leaf litter. Oikos

Gobat, J.-M., Aragno, M., Matthey, W., 1998. Le sol vivant. Presses Polytechniques et Universitaires Romandes, Lausanne, 519 pp.

Green, R.N., Trowbridge, R.L., Klinka, K., 1993. Towards a taxonomic classification of humus forms. Forest Science Monograph 29, 1-46.

Hedde, M., Aubert, M., Bureau, F., Margerie, P., Decaens, T., 2007. Soil detritivore macroinvertebrate assemblages throughout a managed beech rotation. Annals of Forest Science 64, 219-228. 
442

443

444

445

446

447

448

449

450

451

452

453

454

455

456

457

458

459

460

461

462

463

464

Hobbie, S.E., Reich, P.B., Oleksyn, J., Ogdahl, M., Zytkowiak, R., Hale, C., Karolewski, P., 2006. Tree species effects on decomposition and forest floor dynamics in a common garden. Ecology 87, 2288-2297.

Idol, T.W., Pope, P.E., Ponder, F., 2002. Changes in microbial nitrogen across a 100-year chronosequence of upland hardwood forests. Soil Science Society of America Journal 66, $1662-1668$.

Jabiol, B., Brêthes, A., Ponge, J.F., Toutain, F., Brun, J.J., 2007. L'humus sous toutes ses formes. École Nationale du Génie Rural, des Eaux et Forêts, Nancy, France.

Karroum, M., Guillet, B., Lottier, N., Disnar, J.R., 2004. Importance et devenir des biopolymères (lignines et polysaccharides) dans les sols d'une chronoséquence de hêtraies (Fagus sylvatica), en forêt de Fougères (France). Annals of Forest Science 61, 221-233.

Karroum, M., Guillet, B., Laggoun-Defarge, F., Disnar, J.R., Lottier, N., Villemin, G., Toutain, F., 2005. Morphological evolution of beech litter (Fagus sylvatica L.) and biopolymer transformation (lignin, polysaccharides) in a mull and a moder, under temperate climate (Fougeres forest, Britany, France). Canadian Journal of Soil Science 85, 405-416.

Laignel, B., Quesnel, F., Lecoustumier, M.-N., Meyer, R., 1998. Variability of the clay fraction of the clay with flints of the western part of the Paris Basin. Comptes Rendus de l'Académie des Sciences de Paris, Series IIa, Earth and Planetary Science 326, 467-472.

Lavelle, P., Spain, A.V., 2001. Soil Ecology. Kluwer, Dordrecht.

Lebret, M., Nys, C., Forgeard, F., 2001. Litter production in an Atlantic beech (Fagus sylvatica L.) time sequence. Annals of Forest Science 58, 755-768.

Olson, J.S., 1963. Energy storage and the balance of producers and decomposers in ecological systems. Ecology 44, 322-331. 
Pickett, S.T.A., 1989. Space-for-time substitution as an alternative to long-term studies. In: Likens, G.E. (Ed.), Long-term studies in ecology. Springer-Verlag, New-York, pp. 110135.

Ponge, J.-F., 2003. Humus forms in terrestrial ecosystems: a framework to biodiversity. Soil Biology and Biochemistry 35, 935-945.

Ponge, J.-F., André, J., Zackrisson, O., Bernier, N., Nilsson, M.-C., Gallet, C., 1998. The forest regeneration puzzle. Bioscience 48, 523-528.

Ponge, J.F., Delhaye, L., 1995. The heterogeneity of humus profiles and earthworm communities in a virgin beech forest. Biology and Fertility of Soils 20, 24-32.

Ranger, J., Marques, R., Colinbelgrand, M., Flammang, N., Gelhaye, D., 1995. The dynamics of biomass and nutrient accumulation in a Douglas-fir (Pseudotsuga menziesii Franco) stand studied using a chronosequence approach. Forest Ecology and Management 72, 167-183.

R Development Core Team, 2008. R: A language and environment for statistical computing. In: R Foundation for Statistical Computing, Vienna, Austria.

Royston, P., 1982. An extension of Shapiro and Wilk's W test for normality to large samples. Applied Statistics 31, 115-124.

Saarsalmi, A., Starr, M., Hokkanen, T., Ukonmaanaho, L., Kukkola, M., Nojd, P., Sievanen, R., 2007. Predicting annual canopy litterfall production for Norway spruce (Picea abies (L.) Karst.) stands. Forest Ecology and Management 242, 578-586.

Salmon, S., Mantel, J., Frizzera, L., Zanella, A., 2006. Changes in humus forms and soil animal communities in two development phases of Norway spruce on an acidic substrate. Forest Ecology and Management 237, 47-56. 
Sariyildiz, T., Anderson, J.M., 2003a. Interactions between litter quality, decomposition and soil fertility: a laboratory study. Soil Biology and Biochemistry 35, 391-399.

Sariyildiz, T., Anderson, J.M., 2003b. Decomposition of sun and shade leaves from three deciduous tree species, as affected by their chemical composition. Biology and Fertility of Soils 37, 137-146.

Sariyildiz, T., Anderson, J.M., 2005. Variation in the chemical composition of green leaves and leaf litters from three deciduous tree species growing on different soil types. Forest Ecology and Management 210, 303-319.

Starr, M., Saarsalmi, A., Hokkanen, T., Merila, P., Helmisaari, H.S., 2005. Models of litterfall production for Scots pine (Pinus sylvestris L.) in Finland using stand, site and climate factors. Forest Ecology and Management 205, 215-225.

Taylor, A.F.S., Martin, F., Read, D.J., 2000. Fungal diversity in ectomycorrhizal communities of Norway spruce [Picea abies (L.) Karst.] and beech (Fagus sylvatica L.) along north-south transects in Europe. In: Schulze, E.D. (Ed.), Carbon and nitrogen cycling in European forest ecosystems. Springer-Verlag, Berlin, pp. 343-365.

Trap, J., Bureau, F., Akpa-Vinceslas, M., Chevalier, R., Aubert, M., 2009. Changes in soil N mineralization and nitrification pathways along a mixed forest chronosequence. Forest Ecology Management 258, 1284-1293.

Verhoef, H.A., 1995. Litterbag method. In: Alef, K., Nannipieri, P. (Eds.) (Ed.), Methods in applied soil microbiology and biochemistry. Academic Press, London, pp. 485-487. 
511 Figure 1. Leaves, reproductive organs and wood production (expressed in $\mathrm{t} \mathrm{ha}^{-1} \mathrm{yr}^{-1}$ ) according to 512 silvicultural phases in a pure beech chronosequence in Eawy forest, France. Data are means.

513 Vertical bars correspond to standard deviation. Letters (a and b) refer to significant differences 514 between silvicultural phases according to one-way ANOVA and Tukey HSD test $(\mathrm{P}<0.05$ level, $515 \mathrm{n}=4)$.

517 Figure 2. Total litter production $\left(\mathrm{t} \mathrm{ha}^{-1} \mathrm{yr}^{-1}\right)$ and final litter remaining mass (\% of initial mass) 518 according to silvicultural phases in a pure beech chronosequence in Eawy forest, France. Data are 519 means. Vertical bars correspond to standard deviation. Letters (a, b, x and y) refer to significant 520 differences between silvicultural phases according to one-way ANOVA and Tukey HSD test $(\mathrm{P}<$ 5210.05 level, $\mathrm{n}=4)$.

523 Figure 3. Litter decomposition parameters according to silvicultural phases. Data are means. 524 Vertical bars correspond to standard deviation. The decomposition constant $k\left(\right.$ month $\left.^{-1}\right)$ was 525 calculated from $\left(X_{t} / X_{0}\right)=e^{-k t}$, where $X_{0}$ is the original amount of litter and $X_{t}$ is the amount of 526 litter remaining at time t. Letters (a, b, x and y) refer to significant differences between 527 silvicultural phases according to one-way ANOVA and Tukey HSD test $(\mathrm{P}<0.05$ level, $\mathrm{n}=4)$. 
529 Figure 4. Principal Component Analysis (PCA) performed on organo-mineral horizon properties.

530 (A) Correlations circle showing organo-mineral horizon variables (variables factor map). (B)

531 Scatter diagrams onto the PCA factorial plan (individuals factor maps, silvicultural phase or

532 humus forms are labeled) (C). PCA eigenvalue diagram. 
Table 1. Stand and soil characteristics of the stands in four silvicultural phases along the 130 year pure beech chronosequence in Eawy

Forest, France.

\begin{tabular}{|c|c|c|c|c|c|c|c|c|c|c|c|c|c|c|c|c|}
\hline \multirow[t]{2}{*}{ Silvicultural phases } & \multicolumn{4}{|c|}{ 15-yr-old (SP15) } & \multicolumn{4}{|c|}{ 65-yr-old (SP65) } & \multicolumn{4}{|c|}{ 95-yr-old (SP95) } & \multicolumn{4}{|c|}{ 130-yr-old (SP130) } \\
\hline & 1 & 2 & 3 & 4 & 1 & 2 & 3 & 4 & 1 & 2 & 3 & 4 & 1 & 2 & 3 & 4 \\
\hline Age in 2009 (years) & 15 & 20 & 15 & 15 & 67 & 67 & 67 & 68 & 105 & 93 & 103 & 93 & 137 & 137 & 123 & 123 \\
\hline Last year cut & 2004 & 2003 & 2003 & 2003 & 2003 & 2003 & 2003 & 2004 & 2003 & 2004 & 2002 & 2004 & 2002 & 2003 & 2004 & 2004 \\
\hline Area (ha) & 14.5 & 8.0 & 4.6 & 4.4 & 10.8 & 9.5 & 9.2 & 12.1 & 4.5 & 16.4 & 18.1 & 13.5 & 3.6 & 13.8 & 16.2 & 18.7 \\
\hline Basal area $\left(\mathrm{m}^{2} / \mathrm{ha}\right)$ & 15 & 21 & 22 & 17 & 26 & 30 & 27 & 30 & 20 & 29 & 30 & 22 & 20 & 23 & 20 & 24 \\
\hline Percentage of beech $(\mathrm{G} / \mathrm{ha})^{\mathrm{a}}$ & 100 & 100 & 100 & 100 & 100 & 100 & 100 & 90 & 90 & 100 & 100 & 100 & 90 & 90 & 100 & 100 \\
\hline Humus forms ${ }^{b}$ & $\mathrm{Du}$ & $\mathrm{Du}$ & $\mathrm{H}$ & $\mathrm{Du}$ & $\mathrm{E}$ & $\mathrm{E}$ & $\mathrm{E}$ & $\mathrm{H}$ & Do & $\mathrm{E}$ & $\mathrm{E}$ & $\mathrm{H}$ & $\mathrm{E}$ & Do & $\mathrm{E}$ & $\mathrm{E}$ \\
\hline \multicolumn{17}{|l|}{ Vertical sequence $^{c}$} \\
\hline OLn & $\mathrm{x}$ & $\mathrm{x}$ & $\mathrm{x}$ & $\mathrm{x}$ & $\mathrm{x}$ & $\mathrm{x}$ & $\mathrm{x}$ & $\mathrm{x}$ & $\mathrm{x}$ & $\mathrm{x}$ & $\mathrm{x}$ & $\mathrm{x}$ & $\mathrm{x}$ & $\mathrm{x}$ & $\mathrm{x}$ & $\mathrm{x}$ \\
\hline OLv & $\mathrm{x}$ & $\mathrm{x}$ & $\mathrm{x}$ & $\mathrm{x}$ & $\mathrm{x}$ & $\mathrm{x}$ & $\mathrm{x}$ & $\mathrm{x}$ & $\mathrm{x}$ & $\mathrm{x}$ & $\mathrm{x}$ & $\mathrm{X}$ & $\mathrm{x}$ & $\mathrm{x}$ & $\mathrm{x}$ & $\mathrm{x}$ \\
\hline $\mathrm{OF}$ & $\mathrm{x}$ & $\mathrm{x}$ & $\mathrm{x}$ & $\mathrm{x}$ & $\mathrm{x}$ & $\mathrm{x}$ & $\mathrm{x}$ & $\mathrm{x}$ & $\mathrm{x}$ & $\mathrm{x}$ & $\mathrm{x}$ & $\mathrm{x}$ & $\mathrm{x}$ & $\mathrm{x}$ & $\mathrm{x}$ & $\mathrm{x}$ \\
\hline $\mathrm{OH}$ & & & & & $\begin{array}{l}\mathrm{x} /(\mathrm{x}) \\
<1 \mathrm{~cm}\end{array}$ & $\begin{array}{l}\mathrm{x} /(\mathrm{x}) \\
<1 \mathrm{~cm}\end{array}$ & $\begin{array}{l}\mathrm{x} /(\mathrm{x}) \\
<1 \mathrm{~cm}\end{array}$ & & $\begin{array}{l}x \\
>1 \mathrm{~cm}\end{array}$ & $\begin{array}{l}\mathrm{x} /(\mathrm{x}) \\
<1 \mathrm{~cm}\end{array}$ & $\begin{array}{l}\mathrm{x} /(\mathrm{x}) \\
<1 \mathrm{~cm}\end{array}$ & & $\begin{array}{l}\mathrm{x} /(\mathrm{x}) \\
<1 \mathrm{~cm}\end{array}$ & $\begin{array}{l}x \\
>1 \mathrm{~cm}\end{array}$ & $\begin{array}{l}\mathrm{x} /(\mathrm{x}) \\
<1 \mathrm{~cm}\end{array}$ & $\begin{array}{l}\mathrm{x} /(\mathrm{x}) \\
<1 \mathrm{~cm}\end{array}$ \\
\hline A structure $^{\mathrm{d}}$ & $\mathrm{BM}$ & $\mathrm{BM}$ & $\mathrm{J}$ & $\mathrm{BM}$ & $\mathrm{J}$ & $\mathrm{J}$ & $\mathrm{J}$ & $\mathrm{J}$ & $\mathrm{J}$ & $\mathrm{J}$ & $\mathrm{J}$ & $\mathrm{J}$ & $\mathrm{J}$ & $\mathrm{J}$ & $\mathrm{J}$ & $\mathrm{J}$ \\
\hline Topsoil $\mathrm{pH}^{\mathrm{e}}$ & 4.47 & 3.83 & 3.56 & 3.99 & 3.87 & 3.83 & 3.91 & 4.24 & 3.80 & 3.85 & 3.83 & 3.72 & 3.83 & 3.97 & 3.73 & 3.91 \\
\hline Topsoil C/N & 15.1 & 16.6 & 17.8 & 15.7 & 16.3 & 15.4 & 16.9 & 15.0 & 15.5 & 15.4 & 18.5 & 15.9 & 15.4 & 15.8 & 15.0 & 14.8 \\
\hline Topsoil P $\left(\mathrm{g} \mathrm{kg}^{-1}\right)^{\mathrm{e}}$ & 0.13 & 0.23 & 0.18 & 0.16 & 0.18 & 0.12 & 0.10 & 0.20 & 0.18 & 0.21 & 0.22 & 0.23 & 0.48 & 0.12 & 0.12 & 0.15 \\
\hline Topsoil CEC $\left(\mathrm{cmol}^{+} \mathrm{kg}^{-1}\right)^{\mathrm{e}}$ & 5.21 & 6.19 & 7.43 & 6.95 & 5.69 & 5.66 & 4.99 & 5.25 & 5.74 & 5.56 & 7.09 & 5.60 & 6.17 & 5.71 & 5.28 & 5.75 \\
\hline
\end{tabular}

${ }^{\mathrm{a}}$ Percentage of basal area of beech (G/ha) compared to the total species present in the stand

${ }^{\mathrm{b}}$ With Du : Dy smull; H : Hemimoder; E : Eumoder; Do : Dy smoder (Jabiol et al. 2007)

${ }^{\mathrm{c}}$ With OLn : unmodified leaves less than one year old, OLv : unmodified leaves more than one year old, OF : coarse plant fragments with fine organic matter (FOM), OH : more than $70 \%$ FOM, A: organic-mineral horizon. $\mathrm{x}$ : continuous; $(\mathrm{x})$ : discontinuous

${ }^{\mathrm{d}}$ BM : Biomacrostructured; J : Juxtaposition A (A with massive or single-grain structure but no biological or chemical structure)

${ }^{\mathrm{e}}$ Data are means $(\mathrm{n}=3)$ 
Table 2. Main properties of humus forms occurring along beech forest chronosequences according to Brêthes et al. (1995); Jabiol et al. (2007); Gobat et al., (1998) and correspondence with Green et al. (1993) classification.

\begin{tabular}{|c|c|c|c|c|}
\hline \multirow[t]{3}{*}{ Properties } & \multicolumn{4}{|l|}{ Humus forms } \\
\hline & \multirow{2}{*}{$\begin{array}{l}\text { Mull } \\
\text { Dysmull }\end{array}$} & \multicolumn{3}{|l|}{ Moder } \\
\hline & & Hemimoder & Eumoder & Dysmoder \\
\hline OLn & $x$ & $x$ & $x$ & $x$ \\
\hline OLv & $x$ & $x$ & $x$ & $x$ \\
\hline $\mathrm{OF}$ & $x$ & $x$ & $\times$ & $x$ \\
\hline \multirow[t]{2}{*}{$\mathrm{OH}$} & & & $x /(x)$ & $x$ \\
\hline & & & $<1 \mathrm{~cm}$ & $>1 \mathrm{~cm}$ \\
\hline $\mathrm{O} / \mathrm{A}$ transition & Discontinuity between $\mathrm{O}$ and $\mathrm{A}$ & \multicolumn{3}{|c|}{$\mathrm{O}-\mathrm{A}$ progressive transition } \\
\hline A structure & Biomacros tructured & \multicolumn{3}{|c|}{ juxtaposition $\mathrm{A}^{\$}$} \\
\hline $\mathrm{A} \mathrm{pH}$ & $<5$ & $<4.5$ & $<4.5$ & $<4.5$ \\
\hline $\mathrm{A} C / \mathrm{N}$ ratio & $15-20$ & $20-25$ & $20-25$ & $\leq 25$ \\
\hline Soil fauna main groups & $\begin{array}{l}\text { Anecic earthworms } \\
\text { White rot fungi }\end{array}$ & $\begin{array}{l}\text { Macro- } \\
\text { arthropods }\end{array}$ & \multicolumn{2}{|c|}{$\begin{array}{c}\text { Mesofauna and insecta } \\
\text { larvae }\end{array}$} \\
\hline $\begin{array}{l}\text { Bacterial activity } \\
\text { Fungal activity }\end{array}$ & $\begin{array}{l}+\longleftarrow \\
-\leftarrow\end{array}$ & & & \\
\hline Green et al (1993) & Lepto-moder & Leptomoder & mormoder & \\
\hline
\end{tabular}

$x$ : continuous horizon; $(x)$ discontinuous horizon

\$uxtaposition A : A with massive or single-grain structure but no biological or chemical structure; humified organic matter is juxtaposed to mineral matter 
Table 3. Main properties of the organo mineral horizon (A) according to silvicultural phases in a pure beech chronosequence in Eawy forest, France.

\begin{tabular}{|c|c|c|c|c|c|c|c|c|c|c|c|c|}
\hline \multirow{2}{*}{$\begin{array}{l}\text { Topsoil (A) properties } \\
\text { Total C }\left(\mathrm{g} \mathrm{kg}^{-1}\right)\end{array}$} & \multicolumn{3}{|c|}{ SP15 } & & SP65 & Silvicultural Phases & & SP95 & & \multicolumn{2}{|l|}{ SP130 } & \\
\hline & 54.42 & $(24.92)$ & $\mathrm{a}$ & 41.81 & $(4.63)$ & a & 50.38 & $(14.80)$ & $\mathrm{a}$ & 45.92 & $(8.93)$ & a \\
\hline Total $N\left(\mathrm{~g} \mathrm{~kg}^{-1}\right)$ & 3.26 & $(1.29)$ & $\mathrm{a}$ & 2.62 & $(0.28)$ & a & 3.04 & $(0.71)$ & $\mathrm{a}$ & 2.97 & $(0.52)$ & $\mathrm{a}$ \\
\hline $\mathrm{C} / \mathrm{N}\left(\mathrm{g} \mathrm{kg}^{-1}\right)$ & 16.31 & (1.16) & $\mathrm{a}$ & 15.92 & $(0.88)$ & $\mathrm{a}$ & 16.37 & (1.46) & $\mathrm{a}$ & 15.29 & $(0.41)$ & $\mathrm{a}$ \\
\hline $\mathrm{P}\left(\mathrm{g} \mathrm{kg}^{-1}\right)$ & 0.17 & $(0.04)$ & $\mathrm{a}$ & 0.15 & $(0.05)$ & $\mathrm{a}$ & 0.21 & $(0.02)$ & $\mathrm{a}$ & 0.22 & $(0.17)$ & $\mathrm{a}$ \\
\hline $\mathrm{CEC}\left(\mathrm{cmol}+\mathrm{kg}^{-1}\right)$ & 6.45 & $(0.97)$ & $\mathrm{a}$ & 5.40 & $(0.34)$ & $\mathrm{a}$ & 6.00 & $(0.73)$ & $\mathrm{a}$ & 5.73 & $(0.36)$ & $\mathrm{a}$ \\
\hline $\mathrm{H}\left(\mathrm{cmol}+\mathrm{kg}^{-1}\right)$ & 0.90 & $(0.30)$ & $\mathrm{a}$ & 0.90 & $(0.05)$ & $\mathrm{a}$ & 1.14 & $(0.13)$ & $\mathrm{a}$ & 1.10 & $(0.15)$ & $\mathrm{a}$ \\
\hline $\mathrm{Ca}\left(\mathrm{cmol}+\mathrm{kg}^{1}\right)$ & 1.44 & (1.05) & $\mathrm{a}$ & 0.54 & $(0.25)$ & $\mathrm{a}$ & 0.72 & $(0.39)$ & $\mathrm{a}$ & 0.39 & $(0.15)$ & $\mathrm{a}$ \\
\hline $\mathrm{Mg}\left(\mathrm{cmol}+\mathrm{kg}^{-1}\right)$ & 0.37 & $(0.07)$ & $\mathbf{a}$ & 0.21 & $(0.03)$ & b & 0.27 & $(0.07)$ & $\mathbf{a b}$ & 0.22 & $(0.04)$ & b \\
\hline $\mathrm{Na}\left(\mathrm{cmol}+\mathrm{kg}^{-1}\right)$ & 0.09 & $(0.05)$ & a & 0.06 & $(0.01)$ & a & 0.07 & $(0.01)$ & $\mathrm{a}$ & 0.07 & $(0.01)$ & $\mathrm{a}$ \\
\hline $\mathrm{K}\left(\mathrm{cmol}+\mathrm{kg}^{-1}\right)$ & 0.21 & $(0.04)$ & $\mathrm{a}$ & 0.18 & $(0.03)$ & $\mathrm{a}$ & 0.26 & $(0.06)$ & $\mathrm{a}$ & 0.21 & $(0.05)$ & $\mathrm{a}$ \\
\hline Fer $\left(\mathrm{cmol}+\mathrm{kg}^{-1}\right)$ & 0.07 & $(0.06)$ & $\mathrm{a}$ & 0.07 & $(0.04)$ & $\mathrm{a}$ & 0.05 & $(0.02)$ & $\mathrm{a}$ & 0.08 & $(0.03)$ & $\mathrm{a}$ \\
\hline $\mathrm{Mn}\left(\mathrm{cmol}+\mathrm{kg}^{-1}\right)$ & 0.19 & $(0.10)$ & $\mathrm{a}$ & 0.21 & $(0.10)$ & $\mathrm{a}$ & 0.23 & $(0.07)$ & $\mathrm{a}$ & 0.19 & $(0.05)$ & $\mathrm{a}$ \\
\hline $\mathrm{Al}\left(\mathrm{cmol}+\mathrm{kg}^{-1}\right)$ & 3.79 & $(1.52)$ & $\mathrm{a}$ & 3.91 & $(0.49)$ & $\mathrm{a}$ & 4.14 & $(0.37)$ & $\mathrm{a}$ & 4.11 & $(0.32)$ & $\mathrm{a}$ \\
\hline $\mathrm{pH}_{\mathrm{water}}$ & 3.97 & $(0.38)$ & $\mathrm{a}$ & 3.97 & $(0.19)$ & $\mathrm{a}$ & 3.80 & $(0.06)$ & $\mathrm{a}$ & 3.86 & $(0.10)$ & $\mathrm{a}$ \\
\hline $\mathrm{pH}_{\mathrm{KCl}}$ & 3.33 & $(0.25)$ & $\mathrm{a}$ & 3.20 & $(0.06)$ & $\mathrm{a}$ & 3.09 & $(0.04)$ & $\mathrm{a}$ & 3.10 & $(0.09)$ & $\mathrm{a}$ \\
\hline$\Delta \mathrm{pH}$ & 0.64 & $(0.14)$ & $\mathrm{a}$ & 0.77 & $(0.14)$ & $\mathrm{a}$ & 0.71 & $(0.06)$ & $\mathrm{a}$ & 0.76 & $(0.12)$ & $\mathrm{a}$ \\
\hline
\end{tabular}

Data are means (SD). Letters (a and b) refer to significant differences among silvicultural phases according to Kruskal-Wallis rank sum test and Multiple comparis on tests after Kruskal-Wallis test $(\mathrm{P}=0.05$ level, $\mathrm{n}=4)$ 
Table 4. Stepwise multiple regressions with backwards elimination of litter production or decay rate with soil morphological variables.

\begin{tabular}{lll}
\hline Soil morphological variables & Litter production & Litter decay rate $(\boldsymbol{k})$ \\
\hline Leaf fragments in OLn & $\mathrm{X}(+)$ & \\
Earthworm casts in OLn & $\mathrm{X}(-)^{*}$ & \\
Bleached leaves in OLv & $\mathrm{X}(+)^{* *}$ & \\
Live roots in OLv & $\mathrm{X}(+)^{*}$ & \\
Skeletonized leaves in OLv & & $\mathrm{X}(-)$ \\
Brown leaves in OLv & & $\mathrm{X}(-)$ \\
OF maximum thickness & $\mathrm{X}(+)^{*}$ & $\mathrm{X}(-)^{* *}$ \\
OH maximum thickness & & $\mathrm{X}(-)^{* *}$ \\
$P$ value & $* *$ & $*$ \\
$\mathbf{R}^{2}$ & $\mathbf{0 . 8 9}$ & $\mathbf{0 . 6 2}$ \\
\hline
\end{tabular}

An " $\mathrm{X}$ " indicates that the variable was included in the model from the multiple regression analysis. The sign of the relationship between significant soil morphological variables and litter production or decay rates is indicated between brackets.

$* P<0.05$.

$* * P<0.01$.

$* * * P<0.001$. 


\section{Appendix 1. Morphological variables used to determine humus forms within each stand of a 130-}

\section{yr-old pure beech chronosequence in Eawy forest, France.}

\begin{tabular}{|c|c|c|c|}
\hline Soil layers ${ }^{a}$ & Variables & Codes & Modalities \\
\hline \multirow[t]{3}{*}{ OLn } & Leaf fragments & OLnfg & Percentage \\
\hline & Skeletonized leaves & OLnsk & Percentage \\
\hline & Macrofaunal faeces & OLnMfae & Nomber per square meters \\
\hline \multirow[t]{11}{*}{ OLv } & Maximum thickness & OLvMt & Centimeters \\
\hline & Minimum thickness & OLvmt & Centimeters \\
\hline & Leaf fragments & OLvfg & Percentage \\
\hline & Skeletonized leaves & Olvsk & Percentage \\
\hline & Macrofaunal faeces & OLvMfae & Nomber per square meters \\
\hline & Bleached leaves & OLvBl & Percentage \\
\hline & Brown leaves & $\mathrm{OLvBr}$ & Percentage \\
\hline & Cover & OLvrec & Percentage \\
\hline & Compacted leaves & OLvCom & From 1 to 4 (1: no compact, 2 : slightly compact, 3 : moderately compact, 4 : strongly compact) \\
\hline & Mycelium & OLvmy & From 0 to 3 ( 0 : absent, 1 : rare, 2 : moderately present, 3 : abundant) \\
\hline & Living roots & OLro & From 0 to 3 ( 0 : absent, 1 : rare, 2 : moderately present, 3 : abundant) \\
\hline \multirow[t]{10}{*}{ OF } & Maximum thickness & OFMt & Centimeters \\
\hline & Minimum thickness & OFmt & Centimeters \\
\hline & Leaf fragments & OFfg & Pourcentage \\
\hline & Fine organic matter & OFfog & Pourcentage \\
\hline & Macrofaunal faeces & OFMfae & Nomber per square meters \\
\hline & Bleached leaves & OFBl & Pourcentage \\
\hline & Cover & OFrec & Pourcentage \\
\hline & Compacted leaves & OFCom & From 1 to 4 (1: no compact, 2 : slightly compact, 3 : moderately compact, 4 : strongly compact) \\
\hline & Mycelium & OFmy & From 0 to 3 (0: absent, 1 : rare, 2 : moderately present, 3 : abundant) \\
\hline & Living roots & OFro & From 0 to 3 ( 0 : absent, 1 : rare, 2 : moderately present, 3 : abundant) \\
\hline \multirow[t]{7}{*}{$\mathbf{O H}$} & Maximum thickness & OHMt & Centimeters \\
\hline & Minimum thickness & OHmt & Centimeters \\
\hline & Fine organic matter from faunal faeces & OHffog & Percentage \\
\hline & Plant fine organic matter & OHvfog & Percentage \\
\hline & Cover & OHrec & Percentage \\
\hline & Mycelium & OHmy & From 0 to 3 (0: absent, 1 : rare, 2 : moderately present, 3 : abundant) \\
\hline & Living roots & OHro & From 0 to 3 ( 0 : absent, 1 : rare, 2 : moderately present, 3 : abundant) \\
\hline \multirow[t]{5}{*}{ A } & Maximum thickness & AMt & Centimeters \\
\hline & Minimum thickness & Amt & Centimeters \\
\hline & Agregate size & Aas & Millimeters \\
\hline & Structure & Ast & From 1 to 4 (1: without aggregate, 2 : slightly aggregate, 3 : moderately aggregate, 4 : strongly aggregate) \\
\hline & Living roots & Aro & From 0 to 3 (0: absent, 1 : rare, 2 : moderately present, 3 : abundant) \\
\hline
\end{tabular}

\footnotetext{
${ }^{a}$ According to Jabiol et al. 2007. OLn: New. OLv: slightly altered.
} 

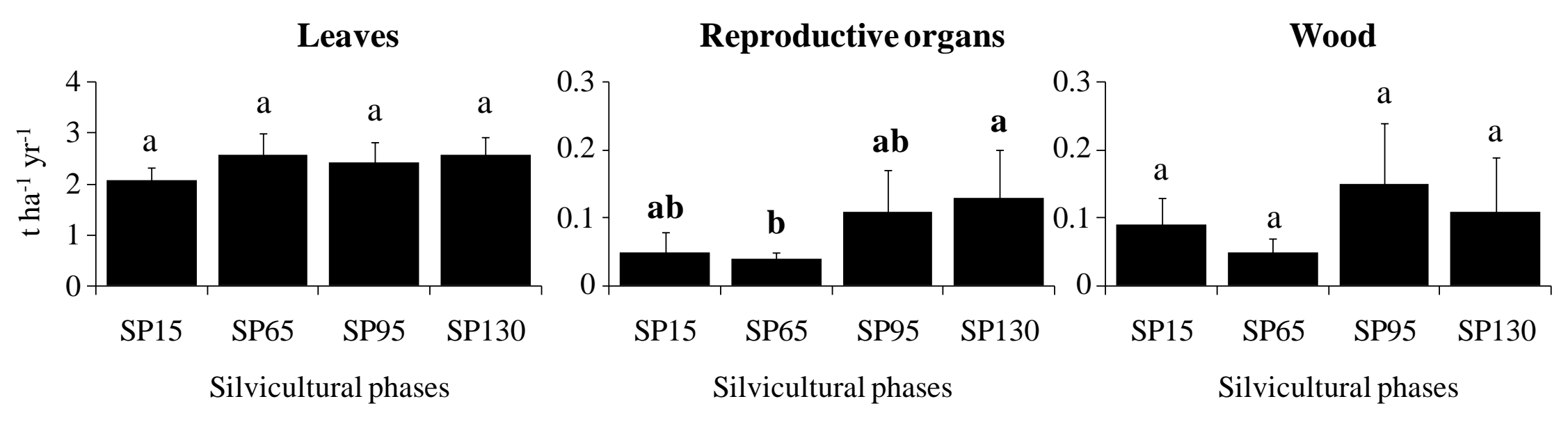


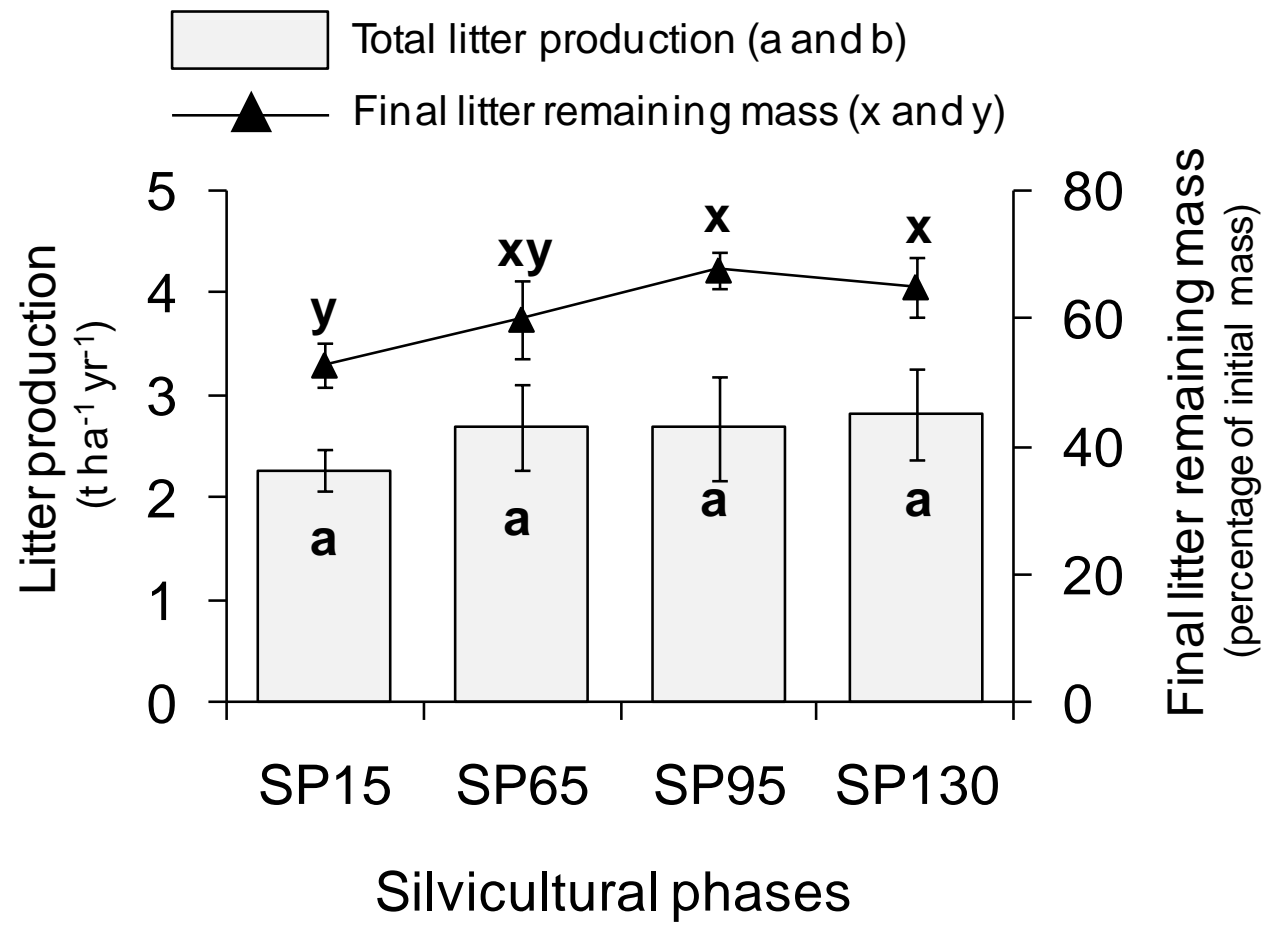




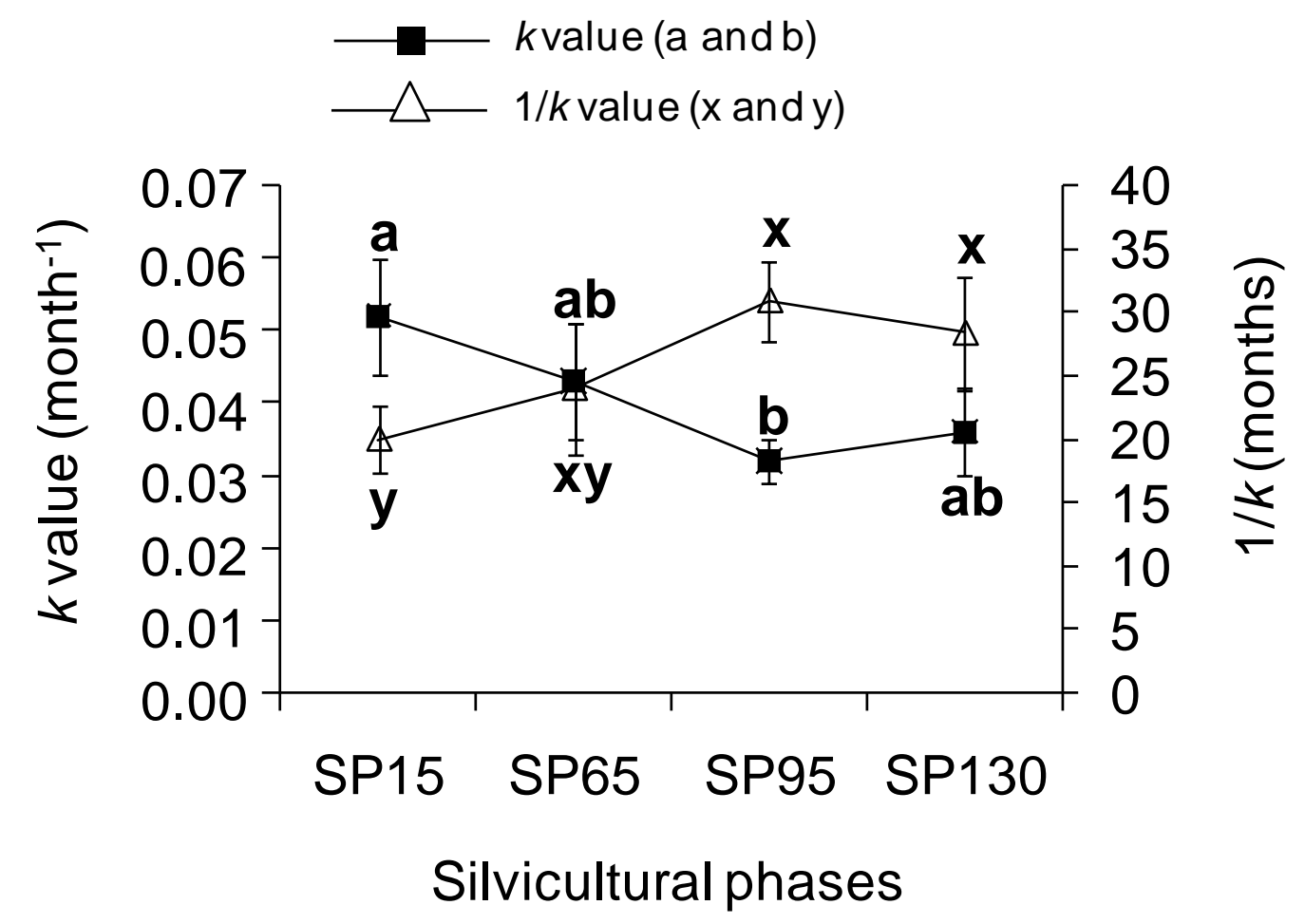



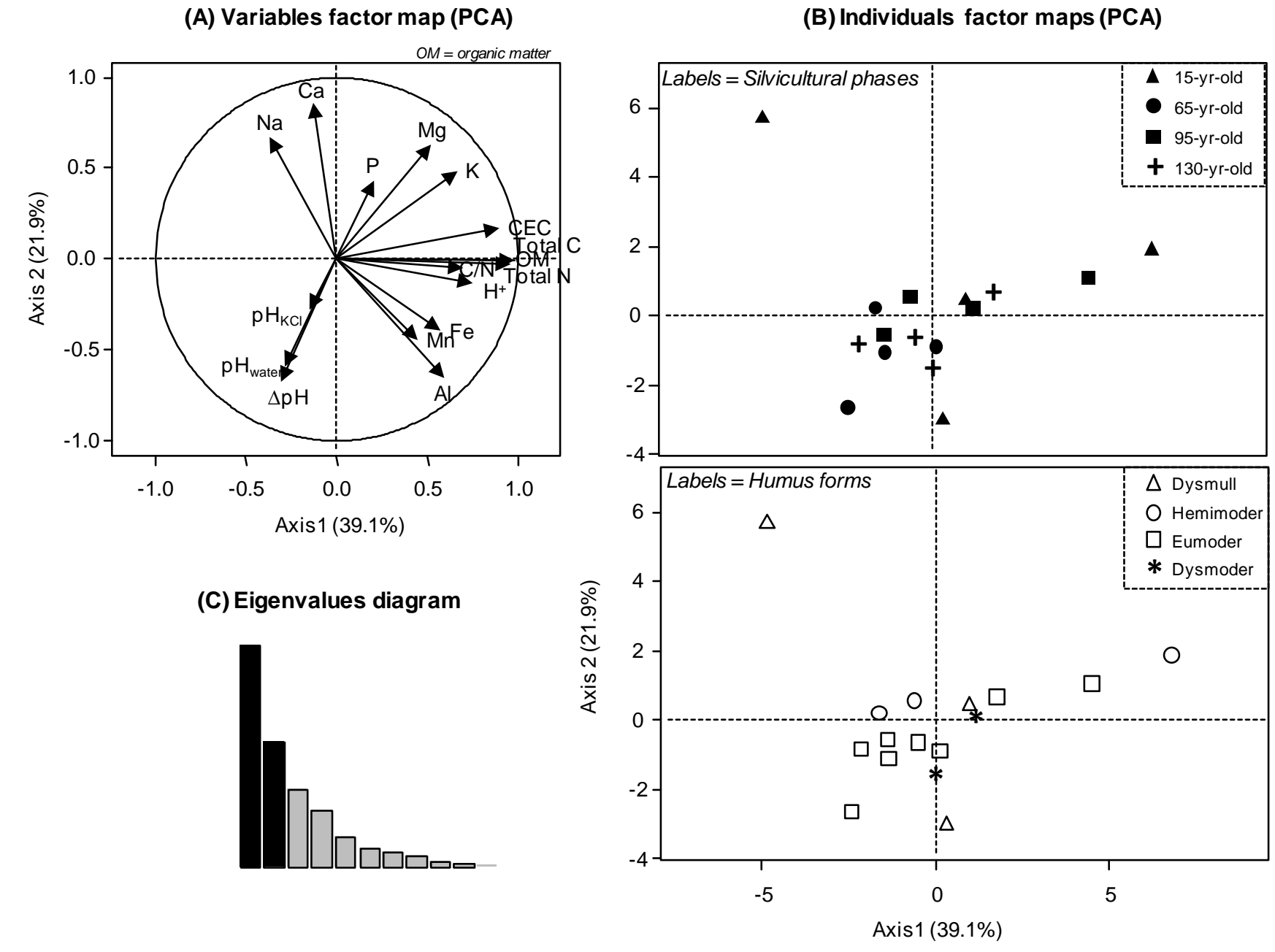

C) Eigenvalues diagram

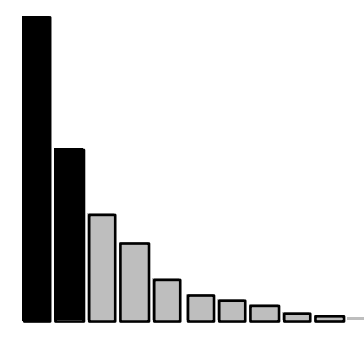

(B) Individuals factor maps (PCA) 